\title{
Analysing the Influence of Technology on the Business Performance of Rattan Processing SME's in South Kalimantan
}

\author{
Iwan Inrawan Wiratmadja ${ }^{\dagger}$ \\ Bandung Institute of Technology Bandung 40132, INDONESIA \\ E-mail: imansoer@yahoo.com, iwan@lspitb.org \\ Rajesri Govindaraju \\ Bandung Institute of Technology Bandung 40132, INDONESIA \\ E-mail: rajesri_g@yahoo.com \\ Evy Setiawati \\ Institute for Industrial Research and Standardization Banjarbaru Kalimantan, INDONESIA \\ E-mail: evy_baristand@yahoo.com
}

Received, January 7, 2011; Revised, April 8, 2011; Accepted, May 11, 2011

\begin{abstract}
Technology is one of the major competitive advantages for small and medium enterprises (SME), especially ones operating in the manufacturing sector. Increasing technological capabilities is the basis for SME's business performance improvement. The main problem of SME's is a limitation in the areas of production facilities, technology, and human resources. Some of these constraints cause a decline in business performance and competitiveness of SME's. In this case analysis of technology components has to be carried out to determine the effect of technology on SME's business performance improvement. This study aims to measure the components of technology and to analyze the influence of each technology component on business performance of rattan processing SME's in South Kalimantan. The assessment is carried out on the technoware, humanware, inforware, and orgaware components using the technometric method (UNESCAP). Business performance is measured through a combination of financial and non-financial aspects deducted from financial and marketing figures. Analysis of the influence of technology components on business performance of SME's is done using the Structural Equation Model (SEM) with Partial Least Square software (PLS). Data is collected through interviews and questionnaires from 21 rattan processing SME's in South Kalimantan that produce rattan furnitures. The results show that the value of the contribution of technology (TCC) to the performance of rattan processing SME's in South Kalimantan is still quite low. Analysis of the results shows a direct influence of technoware and humanware on business performance, while orgaware influences business performance indirectly through humanware.
\end{abstract}

Keywords: Technology, Business Performance, Rattan Processing, SME’s, UNESCAP.

\section{INTRODUCTION}

Small and medium industries (SMI) are generally dominated by labor intensive industries that have relatively short chain so that the creation of added value is also relatively small (Department of Industry, 2008). These labor-intensive industries are considered less able to compete with their competitors from other countries (Wie, 2006). However, because of the large population of business units, the contribution to the economy remains very large. One of the flagship products of Indonesian SMI is processed rattan products. Competitiveness of Indonesian processed rattan products is still low compared to competitor countries like China, Taiwan, Vietnam and Italy. China's exports of rattan products in 2002 is still balanced with Indonesia amounted to U.S. $\$ 340,000$, but in the year 2006 China's exports have increased by 4 (four) times, while for Indonesia as a

† : Corresponding Author 
producer of raw rattan, rattan product export activity decreased (Department of Industry, 2007). On the other hand, world demand for rattan products has increased, primarily from the Netherlands and the United States (Harja, 2009). This increase in world demand is an opportunity for Indonesian rattan processing industry to improve its competitiveness through the expansion of export markets.

In relation to the production process, technology is considered as a tool of transformation of inputs into outputs. Technology is a combination of hardware and software that consists of 4 (four) components, namely technoware, humanware, inforware, and orgaware (THIO) (UNESCAP, 1989). Technology is a specific function, in which all THIO components are needed in the manufacturing process (Saha and Islam, 1998). To be able to take advantage of optimal technology, industrial actor at the company level require accurate and precise tools for measuring how far the gap of the company's technology status compared to its competitors status or the state of the art (Mata et al., 1995). Performance is the key success indicators that show how far the company is in realizing its goals. To ensure long-term business success, companies must develop core competencies that differentiate it from its competitors. This research aims at developing a model that show the relationship between technology components and business performance of rattan processing SMI so that the model can be used as a basis for defining a relevant strategy to improve business performance.

\section{RESEARCH MODEL}

The basic models used as in developing a conceptual model in this research include models developed by Lopez-Acevedo (2002), Sharif (1986), Benito (2007) and Morgan (2009). Lopez-Acevedo (2002) explains that the technology affects business performance of SMEs. The model developed by Sharif (1986) describes that technology as a combination of (4) four basic components that are dynamically integrated in a transforma-

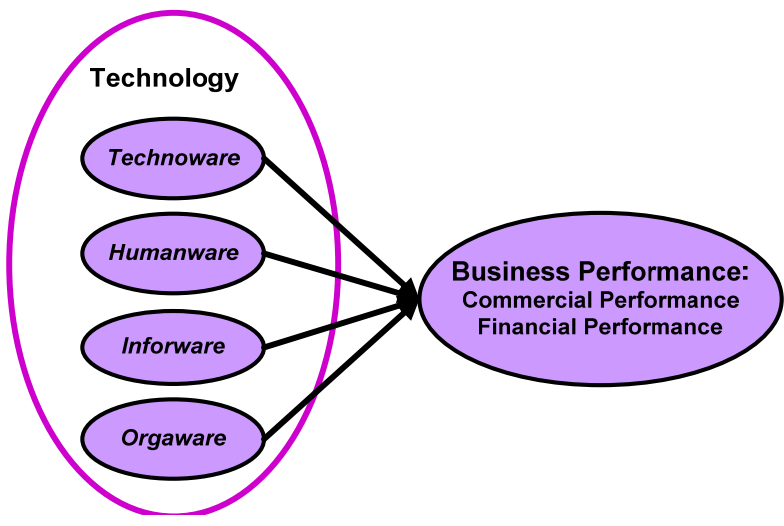

Figure 1. Research Model. tion process, namely technoware component $(\mathrm{T})$, humanware $(\mathrm{H})$, inforware $(\mathrm{I})$, and orgaware $(\mathrm{O})$. Meanwhile, in the relation with business performance, the model developed by Benito (2007) and the model of Morgan (2009) are used in building the research model. Benito (2007) explains that the performance of the business consists of commercial performance (sales growth, reputation and image, customer satisfaction, market share, the success of launching new products) and financial performance (return on investment, profit as a percentage of sales, labor productivity), whereas Morgan (2009) explains that performance is measured based on 2 (two) approaches: (1) the subjective approach to explain the effectiveness of the market which consists of share growth relative to competitors, the acquisition of new customers, increasing sales, sales revenue growth, and (2) an objective approach (rate of return), consisting of Return on Investment and Return On Sales. The research model developed in this research is presented in Figure 1.

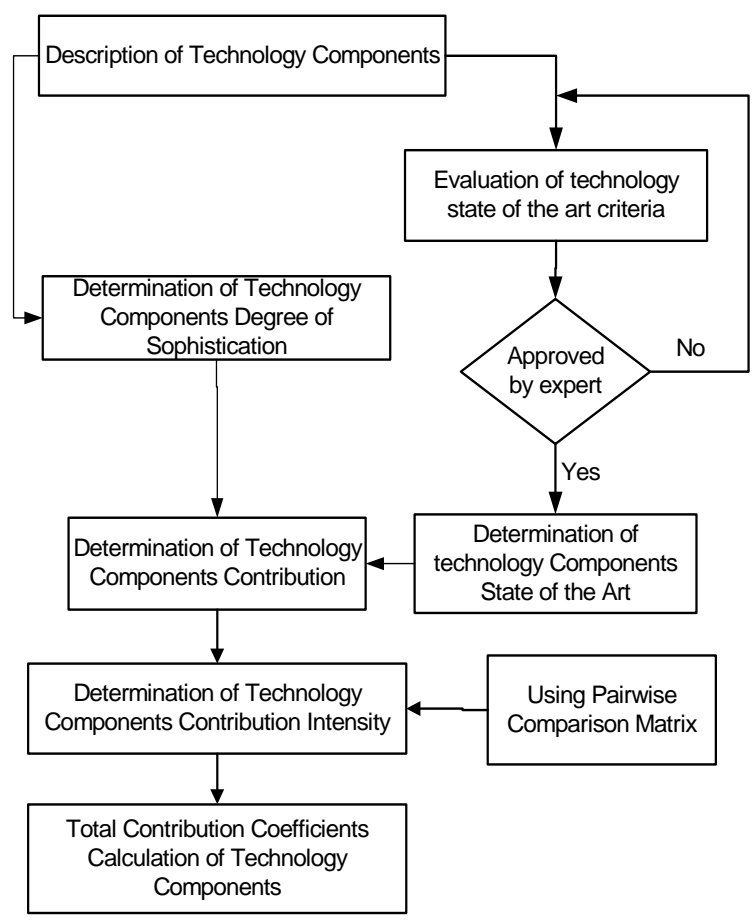

Figure 2. Technology Measurement using Valuation Metrics.

In this study, measurement of technology content is done using valuation metrics method (Figure 2), which consists of 5 (five) stages, namely: the estimation of the degrees of sophistication, the state-of-the-art assessment, determination of the contribution coefficient technology, the determination of the intensity of the contribution of technology components, and determination of total contribution coefficient (TCC) (UNESCAP, 1989). Meanwhile, effective performance measurement system should involve all relevant performance variables to achieve success and growth (O'Regan, 2005). Therefore perform- 
ance measurement systems must involve not only financial measures, but also non-financial ones. The assessment of the company's business performance in this study was done based on the elaboration of the Benito (2007) model and Morgan (2009) model which consists of financial performance (profit growth) and marketing performance (customer satisfaction, customer acquisition, market share, sales growth, and new product development). The assessment of the relationship between technology components (THIO) and business performance is done using Structural Equation Model (SEM) method by the support of Partial Least Square (PLS).

\section{DATA COLLECTION AND PROCESSING}

Empirical research was done at rattan processing SMEs in South Kalimantan, which have a similarity of products and production processes, namely rattan furniture producing SMI. Using non-probability purposive sampling approach, 21 SMEs were used as the data collection sample.

Questionnaires have been prepared based on generic criteria defined by UNESCAP (1989) which consists of technology components evaluation questionnaires, com-

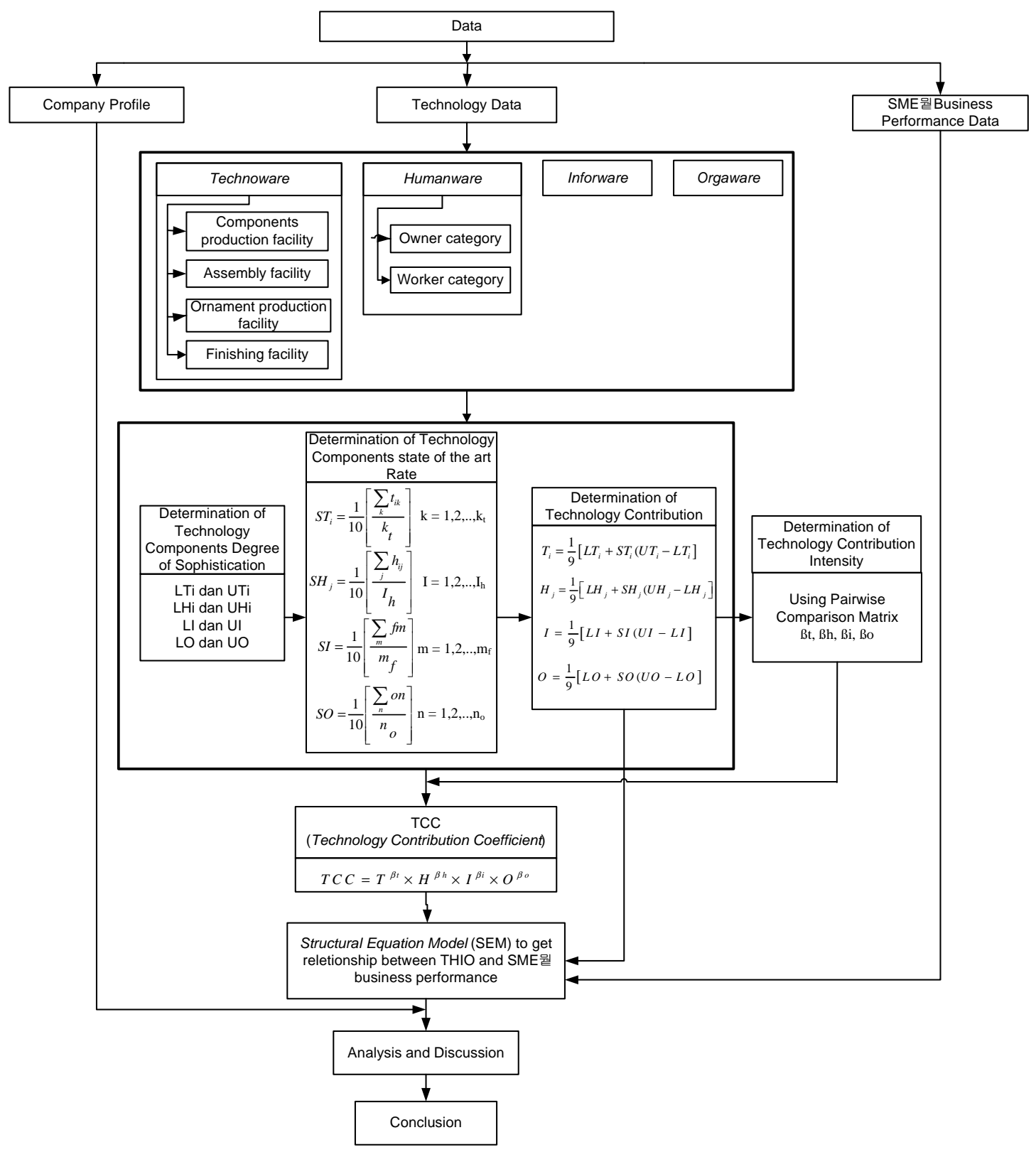

Figure 3. Data Processing Stage. 
pany profiles questionnaires, questionnaires measuring the degree of technological sophistication, the questionnaires measuring the state-of-the-art technology, and the matrix of pairwise comparison questionnaires. Meanwhile, interviews were conducted to fill in the questionnaires which have been compiled. The questionnaire to measure the company's business performance was developed based on Benito (2007) and Morgan (2009) which contains the company's financial performance and marketing performance data. Data related to the technology that consists of technoware, humanware, inforware, and orgaware was processed using metrics developed by UNESCAP (1989). The linkage between technology components and business performance was processed using PLS (see Figure 3).

\section{RESULT AND ANALYSIS}

Based on the analysis of structural equation models, this study found certain patterns that explain the relationship between the four components of technology, namely technoware, humanware, inforware and orgaware and the company's business performance. The result of data processing is presented in Table 1.

Table 1. Correlation pattern from the $3^{\text {rd }}$ stage modification.

\begin{tabular}{|c|c|c|c|}
\hline $\begin{array}{c}\text { Relationship } \\
\text { Between } \\
\text { Construct }\end{array}$ & Effect & $\begin{array}{l}\text { Parameter } \\
\text { Coefficient }\end{array}$ & T-test \\
\hline $\begin{array}{l}\text { Technoware } \\
\rightarrow \text { Business } \\
\text { Performance } \\
\end{array}$ & \multirow{4}{*}{$\begin{array}{l}\text { Direct } \\
\text { Effect }\end{array}$} & 0.509 & $\begin{array}{c}2.242 \\
\text { (significant) }\end{array}$ \\
\hline $\begin{array}{l}\text { Humanware } \\
\rightarrow \text { Business } \\
\text { Performance }\end{array}$ & & 0.482 & $\begin{array}{c}3.463 \\
\text { (significant) }\end{array}$ \\
\hline $\begin{array}{l}\text { Inforware } \\
\rightarrow \text { Business } \\
\text { Performance }\end{array}$ & & 0.272 & $\begin{array}{c}0.931 \\
\text { (not signifi- } \\
\text { cant) }\end{array}$ \\
\hline $\begin{array}{l}\text { Orgaware } \\
\rightarrow \text { Humanware }\end{array}$ & & 0.684 & $\begin{array}{c}5.173 \\
\text { (significant) }\end{array}$ \\
\hline $\begin{array}{l}\text { Orgaware } \\
\rightarrow \text { Business } \\
\quad \text { Performance }\end{array}$ & $\begin{array}{l}\text { Indirect } \\
\text { Effect }\end{array}$ & 0.330 & $\begin{array}{c}3.139 \\
\text { (significant) }\end{array}$ \\
\hline
\end{tabular}

The best correlation pattern was obtained from the modification in the third stage. The results shows that each of the four technology components is able to explain and has a relationship to business performance. Furthermore these results are in line with the actual conditions of the rattan furniture SMI in the South Kalimantan.

As can be seen in Table 1, the components that have significant direct influence on business performance are technoware and humanware with coefficient value 0.509 and 0.482 while inforware does not have significant direct influence on business performance. The orgaware component affects business performance indirectly through the humanware component with coeficient value of 0.684 . The value of the coefficient indicates the importance of each variable on a relative basis. The higher the value of the variable coefficient the more important the variable compared to other variables (Ghozali, 2007). The difference between technoware and humanware coefficient is very small. This indicates that these two components are almost equally important towards the achievement of business performance improvement.

Based on the pattern of relationship between technology components and business performance it can be explained that the role and capabilities of human resources (humanware) is considered important in the production of rattan furniture. The human resources of the rattan furniture SMI in South Kalimantan have the technical skills required in the production process to deliver good quality products. Rattan furniture production process requires special skills such as rattan bending techniques and weaving techniques. This deals with the nature of the product which is a craft product that requires a high artistic value, so that the shape and design are major factors in meeting consumer preferences. Production skills of craftsmen are generally acquired through experience, while skills in other fields such as product design needs to be further developed. Education and training provided by local government both in the field of production engineering and product design is still limited. Limited education and training on production techniques provided by the government inhibits the process of human resource development.

The existence of physical facilities (technoware) is considered very important in the production of rattan furniture. In improving the quantity and quality of product, the transformation process depends a lot on the capability of production facilities. In general, small scale industries still use the physical facilities (technoware) which are manual/semi-manual devices. This condition results in low SME's production capability. This condition is associated with a lower ability of the company in terms of capital, making it difficult to make improvements or to do equipment purchases. The company currently requires a variety of high-tech devices to improve the quantity and quality of production. Equipment with high technological level enables companies to improve business performance.

The capabilities of the SMI in terms of information (inforware) is still limited at the stage of understanding the basic principles and usage of facilities. Access to such information regarding market opportunities, consumer preferences, and procedures for marketing the products is still limited. Progress in information technology has not been used to support business improvement. Currently the rattan furniture SMIs rely only on the trading companies to market their products. This is caused by lack of access to information. Therefore the 
ability of the SMI's actors in accessing the information and utilizing the information optimally is necessary to be facilitated. Information technology is needed to improve the speed of delivering information to consumers and to facilitate the collection of information about consumer and market data.

Currently the SMI's organizational capability resides at the stage in which the organization is building a network and is ready to compete. Organizations in the SMI can be considered to be less developed. Owners who led the company's operations directly and the absence of a clear division of tasks indicates that the organizations within the SMI have limitation regarding their managerial system and formal management processes. The companies tend to establish cooperation with other companies to market their products through subcontracting system. The results of the study also showed that the organization component (orgaware) significantly affect humanware component. Organization is the optimal place to manage human resources. This may imply that the organization's system and good management practices can support the development of human resources capabilities.

The findings above also showed that the improvement of the rattan furniture SME's business performance can be done by improving the technology components in the following order of priority: strengthening technoware component, then humanware, and orgaware. Technoware is the most important since the transformation process on the rattan furniture SMI is dependent a lot on the capacity of its production facilities in improving the quantity and quality of production. Technoware improvement can be done by enhancing or purchasing their production facilities. Rattan furniture is handmade product with a high artistic value. Therefore special labor skill (humanware) is needed. Humanware aspects can be improved by strengthening the ability of the organization (orgaware). The organization's system and procedures as well as good management practices can support the development of human resources capabilities.

Regarding the inforware component, although this study found that this component does not have a significant influence on the business performance, this study recommends the SMEs to put enough effort in providing and processing information into knowledge sources by the support of information technology. This recommendation is based on the survey results that show a low level of IT usage in the SMEs being studied as explain earlier in this section.

\section{CONCLUSION}

Assessment of the linkages between technology and business performance showed that the four components jointly affect business performance. Technoware, and humanware components directly influence business performance, while the orgaware component influence business performance indirectly through humanware component. Rattan furniture SMEs' business performance improvement efforts can be done by enhancing the technology components by, especially the technoware and humanware components. This is based on the fact that the process of transformation in the rattan furniture industries is dependent a lot on the ability of their production facilities (technoware) in improving the quantity and quality of production. Special labor skill (humanware) is very important to be enhanced considering that the rattan furnitures are mostly handmade products with a high artistic value.

\section{REFERENCES}

Benito, J. G. (2007), A Theory of Purchasing's Contribution to Business Performance, Journal of Operations Management, 25, 901-917.

Depperin (2007), The Development of Indonesian Rattan Processing Industries, Jakarta, (in Indonesian Bahasa), http://www.depperin.go.id/ind/publikai/ Siaran_Pers/2007/2007029.HTM.

Ghozali, I. (2007), The Application of Multivariate Analysis using SPSS, Diponegoro University Publisher, Semarang.

Harja, R. (2009), Rattan Manufacturers in Indonesian are Currently Rely on Local Markets, Harian Medan Bisnis, 15 Agustus.

Lopez-Acevedo, G. (2002), Technology and Firm Performance in Mexico, Technical Report JEL. Codes: L60, L20, J3, J38 Mexico-Technology, Wages, and Employment, World Bank Publication.

Mata, F. J., Fuerst, W. L., Barney, J. B. (1995), Information Technology and Sustained Competitive Advantage-A Resource Based Analysis, MIS Quarterly, 19, 487-505.

Morgan, N. A., Vorhies, D. W., Mason, C. H. (2009), Market Orientation, Marketing Capabilities, and Firm Performance, Strategic Management Journal, 30, 909-920.

Saha, G. C. and Islam, N. (1998), Technological Information for Technology Strategy Management, International Journal of the Computer the Internet and Management, 6, 28-41.

Sharif, N. (1986), Measurement of Technology for National Development, Technological Forecasting and Social Change, 29, 119-172.

United Nation's Economic and Social Commission for Asia and the Pacific (Unescap) (1989), Technology Atlas Project: A Framework for Technology-Based Development, Banglore, India.

Wie, T. K. (2006), Technology Competence and the Improvement of Indonesian Industry Competitiveness, Economic Research Institute, Technical Report of Indonesian Science Centre. 